\title{
ЛІТЕРАТУРОЗНАВСТВО
}

DOI 10.31654/2520-6966-2018-10f-91-12-35

УДК 821.161.1(092)

\section{Даріана Блохин}

доктор фрілософії в ділянці педагогіки, професор, член-кор.

Академії наук у Нью Йорку, почесний академік Академії наук вищої школи України

\section{Причини українського національного самогубства Миколи Гоголя}

У статmі автор висвітлює причини українського національного самогубства Миколи Гоголя, зв'язки його з Західною Європою, де він ознайомився з культурою і життям інших народів. Його перебування за кордоном зумовлене переслідуванням з боку російського царського уряду як україния, який писав свої праці російською мовою української тематики $i$ мав проблеми в друкарнях. Пізніше він вобрав тематику із російського життя за царизму, яка була наскрізь правдивою. Микола Гоголь засуджував тогочасний лад, що теж викликало невдоволення царизму. Часто лікувався за кордоном: Бад Емс, Баден-Баден (Німеччина), Марієнбад (Чехія) та ін.

Ключові слова: Баден-Баден, Бад Емс, Рим, Париж, Любек; Залєский, Тургенєв, Погодін; театр, Полтава, українські звичаї, козацький рід, українські пісні.

Хоч М. Гоголь і став російським письменником, але він не міг забути України, ментальні риси якої заполонили його душу. Гоголю, як Вернадському, Архипенкові, не знайшлося місця на Батьківщині, бо умови "бездержавного, напівколоніального життя фрактично гнали їх в еміграцію, позбавляючи можливості працювати на благо свого народу..." (О. Гончар). Ми поділяємо лаконічні думки О. Гончара. Вдамося до простеження історичних аспектів діяльності Миколи Гоголя: характеристики шляху становлення особистості; шукання шляхів спасіння свого таланту та причин падіння особистості великого російського письменника, українця Миколи Васильовича Гоголя, який прожив такий короткий вік (1809-1854). Гоголь мріяв "бути по-справжньому корисним людству": "Я палав незгасним прагненням зробити 
своє життя потрібним для блага держави, я жадав принести хоча б найменшу користь. Тривожними думками, що я не зможу, що мені припинять шлях, завдавши мені глибокого суму. Я поклявся, жодної хвилини короткого життя свого не втрачати, не зробивши його блага" [18]. Так писав Гоголь у своїх "Исповедях".

Для висвітлення обраної проблеми потрібно все-таки хоч частково вдатися до життя і діяльності М. Гоголя, заглянути в історичне минуле нашої України, де криється відповідь на питання роздвоєності душі Гоголя, що привела його до національного і фрізичного самогубства.

А хто були батьки у Гоголя? Українці, в оточенні яких і виховувався Микола Гоголь. Микола народився в містечку Великі Сорочинці 20 березня 1809 року Полтавської губернії. Миколою назвали хлопця на честь чудотворної ікони Святого Миколи.

Як свідчать документи, рід Гоголів бере початок із XVII ст., з часів Хмельниччини. Прадід, Ян Гоголь, вихованець Київської академії. Жили Гоголі в місцевості Янові, звідси і прізвище - Гоголь-Яновський. Дід, Афанасій (Панас) Дем'янович Гоголь (1738-1805), писав у документах, що його предки польської національності, справжнє прізвище Івановський, але він взяв прізвище Гоголь, щоб підкреслити своє благородне козацьке походження. Зналися предки Миколи із гетьманами України - Петром Дорошенком та Іваном Скоропадським.

Один із його предків, Остап Гоголь, був козацьким полковником гетьманом Правобережної України за часів Руїни; другий - Д. П. Трощинський, родич по матері Гоголя, Марії Іванівни, був колишнім міністром юстиції, в минулому бідний "козачок", який повернувся із Петербурга в село Кибинці, створив там домашній театр, був меценатом митців. Тут ставились комедії Василя Опанасовича Гоголя, батька Миколи, автора українських інтерлюдій у простацькому жанрі ("Собака-вівця", "Простак, або Хитрощі жінки, перехитрені москалем").

Батьки Миколи були українці з усіма українськими традиціями. Батько Миколи, Василь Опанасович Гоголь-Яновський (1777-1825), служив при Малоруському поштамті, а в 1805 р. звільнився у чині колезького асесора й одружився з Марією Іванівною Косяровською (1791-1868), першою красунею на Полтавщині.

Микола був старшим сином, його брат Іван (помер у 9 років) i сестри: Марія, Ганна, Єлизавета, Тетяна і Ольга. Дитинство його минуло у мальовничому куточку Полтавщини в с. Василівка (Яновищі), нині с. Гоголеве Шишацького району Полтавської області, в маєтку батьків. Батьки вважалися середняками й мали 1000 десятин землі і 400 душ кріпаків-селян. 
Серед чудової української природи пройшли дитячі та юнацькі роки хлопця. Тут він відкрив для себе світ, сповнений зворушливих, сумних і веселих легенд про козаків. Початкову освіту здобув вдома. У три роки він читав, а в п'ять - малював. Мова була у родині українська, яка глибоко закарбувалася ще у підсвідомості дитини, i після народження вона увійшла у свідому сферу: слова, які дитина чує від батьків, закарбовуються і не зникають протягом усього життя. Навіть у смертній агонії людина говорить своєю рідною мовою.

Потім Микола вчився у Полтавському повітовому училищі (1818-1819). У 1921-28 рр. навчався у Ніжинській гімназії вищих наук князя Безбородька, в одному із кращих гімназій України. Курс навчання тривав 9 років, був ґрунтовним і різнобічним. Плата була дуже високою, 1000 карбованців на рік, але, дякуючи турботам Трощинського, він був зарахований "на казенный кошт".

Гоголь, у результаті домашнього, тепличного виховання, був не підготовлений до самостійного життя в ту страшну пору нищення всього українського. Він вчився в гімназії разом із Віктором Забілою (1808-1869), який, як пише О. Деко в "Солов"ї співають на світанні" [4], ставав на захист Миколи перед хлопцями-верховодами, які насміхалися над тихим хлопцем, вигадували прізвиська, називали його "хохлом". Але, як не кепкували з нього, він писав українською мовою. Микола радив Віктору писати вірші українською мовою, бо "вона така солодка і звична нам з дитинства" [4, с. 52].

Родинні традиції, з одного боку, і перебування Миколи з малечку на Полтавщині серед українського люду, з іншого, безумовно, заклали в душу дитини все українське, хоч у школі навчання проводилося російською мовою (1818-1819 рр. Микола вчився в Полтаві), учням намагалися прищепити російський патріотизм, та діти стихійно лишалися українцями, їх плекала рідна природа, українська пісня, казка, героїчні перекази про козацтво. М. Гоголь читав твори нової літератури: "Енеїда" І. Котляревського, бурлескні поезії П. Гулака-Артемовського, збірники українських пісень Цертелєва і Максимовича. Він читав "Вестник Европы" та інші статті українською мовою [2, с. 45]. У будинку часто бував В. В. Капніст, російський поет українського походження, який був українським автономістом [3, с. 63]. Правда, родина Гоголів була панська, у родинному колі розмовляли українською мовою, а при гостях - російською. Миколу виховували відповідно до "правил хорошого тону", не дозволяючи йому близьких стосунків з дітьми кріпаків, і уже тут у нього закралася думка, що він стоїть вище цих дітей, і це поволі отруювало чисту душу дитини. I Гоголь ріс паничем. Як писав П. Куліш, він ніколи "не знал поселя- 
нина близко. Он видел его только с помещичьяго крильца или из коляски... Он не сиживал с ним рядом; он не бывал его обычным гостем" ("Основа", 1861, кн. 4. с. 79). Паничем ріс вдома, паничем вступив до Ніжинської "Ґимназіи высших наук" (1821-1828), де вчив схоластику російською мовою. Гоголь не був старанним учнем, але мав добру пам'ять і готувався до екзаменів в останні дні і складав, переходячи з класу в клас. Він був слабким у мовах, але мав успіхи в малюванні і російській словесності.

Товариство таких же дітей, як він, - ось що фрормувало духовний образ юнака. Він на все життя мав таких друзів, як Г. І. Висоцький, О. С. Данилевський, М. Прокопович і ін.

Микола ще в гімназійні роки розпочав літературну діяльність. Він багато читає, бере участь у створенні гімназійного журналу, пише вірші, п'єси, а також трагедію "Розбійники", баладу "Дикі рибки", сатири "Дещо про Ніжин, або дурням закон не писаний", "Сніданок у предводителя", "На ярмарку", "Вибори в міському маґістраті", повість "Братья Твердославичи", поема "Ганс Кюхельґартен", "Росія під ярмом татар", він записував українські слова до "Лексикону малороссійского" та ін., з великим успіхом виконує роль актора в театрі, в різних гімназійних постановках. 3 особливим успіхом виконував роль Простакової у "Недорослі" Д. Фонвізіна, але він мріяв не про славу актора, а про письменника. Гоголь-гімназист відвідував передмістя Ніжина, Магерки, знайомиться з селянами, відвідує весілля і заводить книгу "Всякої всячини, або підручну енциклопедію", куди записує замальовки із народного життя, побуту і творчості, які потім використовував у своїх книгах. Особливо великий вплив на нього мав професор політичних і юридичних наук Бєлоусов, людина прогресивних поглядів, талановитий педагог, порядна особистість.

У 1825 р. помирає батько Миколи, коли йому було 15 років. Це був великий удар для всієї родини. Турботи про родину лягли на плечі Миколи, він дає поради, заспокоює маму і думає про майбутнє, хоча самостійності у виборі не мав. Вплив російської школи заглушував цю неглибоку інстинктивну зацікавленість, і він вражений величчю і могутністю Російської імперії. Гоголь відчуває свою Батьківщину як провінцію. Уже в дитячі та юнацькі роки у Миколи склалися умови його душевного роздвоєння. Микола мріє про юридичну кар'єру, хоче приголомшити своїми знаннями всю Росію. Українські враження відсунулись на задній план, він не бачить свого майбутнього, своєї вимріяної кар'єри в Україні.

То були люті часи поневолення України. Російська влада була абсолютною, жодної надії на визволення поневоленої України не 
було. Поволі Україна перетворювалася на глуху провінцію, де не було ніяких перспектив на широке духовне життя, де не було місця для людей Гоголевого розмаху, Гоголевої геніяльності. Українське культурно-національне життя занепадало, народну мову було витіснено зі шкіл і вжитку, її висміювали як діалект, що ним говорять тільки селяни в Україні, російська бюрократія викорчовувала залишки українських державних традицій. Перед Гоголем розкривається національна атмосфрера України початку XIX ст.: знищення гетьманської еліти, яка заніміла у тупому землевласництві, промінявши свої героїчні звитяги на "орання землі"; на тлі руїн бурхливої козацької минувшини падають у летаргічний сон села і хутори; здеморалізована петербурзькими можновладцями українська аристократія, яка стала "дворянством всероссийським". Над Україною нависла руїна як політична, так і духовна: народ спить, боїться підняти голову. Але часто прокидається від грому музики на балах у петербурзьких вищих колах зрадників, "мочеморд", служаків, для яких духовне життя обмежується лише питтям і їжею, а то й розвагами з елементами канібалізму (описано Т. Шевченком у поемі "Сон"). А подекуди в українських поміщиків ще в сонній свідомості тліють іскорки, що нагадують "хто вони і чиї діти". Вони часто підносять чарку "За Українську республіку!" в маєтках українських поміщиків Репніних, Закревських, Тарнавських та ін., але отверезівши, знову впадають в сплячку, історія для них стогне і помирає... Така ж ситуація і в вищих колах, яких Катерина II обдарувала " вольностями дворянства", а внизу - мільйони закріпачених селян на зразок рабського російського кріпацтва. Про їхню безвихідь співають кобзарі, бандуристи, які хоч теж закуті, але ще живі, вони - залишки історичної пам'яті української минувшини. Та Боже Провидіння не спить. Воно посилає нації Месію Т. Шевченка, який незабаром своїм гнівним словом "вигострить сокиру і заходиться вже будить" кличе народ до боротьби. Все це відбувалося на очах молодого Гоголя, сина зубожілого дідича-батька.

Щоб рости і розвиватися, щоб мати можливість виявити свою непересічну особистість, треба було шукати ширших обріїв. I Гоголь, після закінчення Безбородькової гімназії в Ніжині (1828), дев'ятнадцятирічним юнаком, разом зі своїм другом Ол. С. Данилевським, подався на "государственную службу" до вимріяного Петербурга в грудні 1828 р., де проживатиме до 1831 р. Столиця зустрічає його похмуро і з холодом. Але скоро приходить жахливе розчарування, петербурзька зима не така, як полтавська, Росія не така, як його Батьківщина. Тільки тепер він зрозумів, якою жахливою є різниця між бажанням і дійсністю в чужій йому країні, де нікому нема до нього діла. 
Довго не міг знайти роботу, лише в листопаді 1829 р. знайшов посаду рядового чиновника у департаменті державного господарства, а потім став писарем за сприяння поета І. В. Панаєва. Належного одягу М. Гоголь не мав. Ходити в поношеному одязі було принизливо. "Скромніше за мене навряд чи хтось живе у Петербурзі. Я трохи звик до морозу й відбув усю зиму в літній шинелі". Пише він у листі 2 квітня 1830 року. Праця в державних установах дала Гоголю матеріал для майбутніх його творів. У нього виникає бажання підготовити себе до тріумфу в літературі. На початку 1929 року, він робить перші літературні спроби: пише вірш "Італія", ідилічна поема із німецького життя "Ганс Кюхельґартен" (під псевд. В. Алов, 1829), не знаючи, що ії чекатиме. Критика в часописі "Московський телеграф" і в газеті "Северная пчела" була безжалісною. Вона зустрічає отруйні кпини і критику у Н. А. Польового, пізніше поблажливо-співчутливий відгук О. М. Сомова (1830). Гоголь зі своїм слугою Якимом Німченком скупив усі примірники повісті і знищив.

У повному розчаруванні провалом першої спроби і безвиході на успіх, Гоголь відправився за кордон. Він їде до Німеччини, де пробув 2 місяці і повернувся назад морем до Любеку, і знову повертається до Петербурга (вересень, 1829). Він пояснював свою поїздку тим, що Бог вказав йому шлях до чужої землі, а іноді посилався, на якусь ненадійну любов. В дійсності він, як і Сковорода, тікав від самого себе у безсиллі щось змінити, від розладу своїх високих мрій, які не вдається практично здійснити у житті. Иого тягнуло в якусь фантастичну вимріяну країну щастя, яку вбачав у Америці, але замість неї, завдяки Ф.В.Булгаріну, потрапив на службу до III Відділення та довго там не утримався. Отруєний духовною порожнечею і страшною ностальгією за рідним краєм ("Авторская исповедь"), він ще вперто намагається знайти себе в столиці, ще шукає в ній ідеальну "Росію" як продовження "Руси", і чим більше не знаходить, тим більше згадує Україну.

Його чекала служба в департаменті (квітень 1830 р., де він працював до 1832 р.). У цей час (1831-1832) виходять у світ "Вечори на хуторі біля Диканьки", що викликали загальне захоплення, повість "Ніс" - сміливий гротеск. Він заходиться біля написання повісті "Тарас Бульба" (надрукована аж у 1835 р.) - це контраст до столичного життя, де зафіксовано минуле, коли козаки захищали свою суверенність, діяли цілісно, гуртом, як сила, що визначає характер західноєвропейської історії.

У вільний час Микола відвідує Академію мистецтв, займається живописом, набирається нових вражень, які використовує у творах, зокрема, у "Перербурґських повістях". 
Початок 30-х років для Гоголя був піднесеним. Він знайомиться з письменником і критиком О. Сомовим, співредактором "Литературной газеты" А. Дельвігом, В. Жуковським, М. Погодіним, М. Щепкіним, І. Аксаковим, П. Плетньовим. На прикінці 1831 року він знайомиться з О. Пушкіним, з яким на довгий час їх поєднує плідна праця і дружба. Спілкування з Пушкіним справило значний вплив на становлення Гоголя як письменника. Пушкін змінює його тональність "Вечорів на хуторі біля Диканьки": як він писав, що Пушкін змусив його подивитися на справу серйозно. Поет залучає Гоголя до участі в журналі "Современник", де з'являється його стаття "Про рух журнальної літератури", спрямована проти одіозних реакційних журналів Булгаріна, Сеньковського. Пізніше у "Современнику" були надруковані повісті Гоголя "Коляска", "Ніс".

В 1832 р. Гоголь повертається і живе на Полтавщині. Так зароджується ідея твору "Вечера на хуторе близ Диканьки", яку писав 3 1829-1831 рр., де ще концентрується на своїх юнацьких спогадах 3 України, її чарівного світу. Він додав до книги словничок із 129 словами, бо російський читач не знав термінів, які поширені були в українській мові.

У січні 1832 року Гоголь здав у цензуру другий том "Вечорів...", які були вершиною його творчості. О. Пушкін відреагував із захопленням: "Сейчас прочёл "Вечера близ Диканьки. Они изумили меня. Вот настоящая весёлость, искренняя, непринуждённая. Без жеманства, без чопорности. А местами какая поезия, какая чувствительность! Всё это так необыкновенно в нашей литературе, что я доселе не образумился. Мне сказали, что ... наборщики помирали со смеху, набирая его книгу. Мольер и Фильдинг, вероятно, были рады рассмешить своих наборщиков. Поздравляю с истинно весёлою книгою" [7].

Тай і не дивно. Це було нове у російській літературі. Звісно, в поезії панував тоді О. Пушкін, а потім - О. Грибоєдов, Антон Дельвіг, Дм. Веневитинов, О. Боратинський, Микола Язиков, Федір Тютчев (там же). У прозі - Олександр Бєстужев, Фаддей Булгарин, Ол. Вельтман, Микола Погодін. Тодішні російські романи та повісті часто були малохудожні писання, з убогим сюжетом. Час Івана Тургенєва, Федора Достоєвського та Льва Толстого настане пізніше. I можна собі уявити реакцію цих "метрів" на появу на літературному полі імперії книг із сильною метафоричністю, гострими сюжетами, у змісті яких відчувалась присутність духу давньокиївської Русі. От і почалася в російській літературі атака цих "класиків" на твори Гоголя. Це потім, в дебютну пору, його підтримав лише Олександр Пушкін. Гоголь уперше відкрив росіянам Україну, яку вони бачили як провін- 
цію імрперії. Власне Україна стала провінцією лише півстоліття тому, коли 1782 року гетьманська автономія була замінена на губернський адміністративний уряд. От і вони розглядали Гоголя як російським підданим з Полтавської губернії, заснованої 1802 року, дивлячись на нього як на "маленьку людину". А тут він видає такі твори, як "Вечори на хуторі біля Диканьки", (1831-32), "Арабески" та "Миргород" (1835), "Ревізор" (1836), "Мертві душі" (1842) та інші твори, в яких сатирично зображується суспільство Росії, що породжує сваволю й насильство, де процвітає сваволя і насильство, де все більше розвивається жорстокість, несправедливість і байдужість людей, деспотичність суспільства до "маленької людини", що гідність людини оцінюється багатством і знатністю. Гоголь бачить свою долю у такому суспільстві і пише: "Матінко, урятуй твого бідного сина!".

От і почалось переслідування і критика творів М. Гоголя, а найбільше за те, що Гоголь знав більше від цих письменників, він вніс у російську літературу нові віяння. Гоголь єдиний добре знав про українське бароко, що мало розквіт в Україні у XVII-XVIII ст. У його родині ще добре пам'ятали про цю культуру. Ще з дитинства Микола захоплювався бароковою драмою, що представлялася ляльковим вертепом та "шкільною драмою". Гоголь наповнив свою романтику українською демонологією: продаж душі чортові, шукання цвіту папороті, й закопаного скарбу. Ворожнеча між німфою і відьмою, зачарування людської душі. Невичерпним джерелом романтики $€$ пісні у "Вечерах..."; у Гоголя був у щоденнику "Вірш, говорений Потьомкіну запорожцями на світлий празник Воскресения" (барокова поема); він студіював бароковий літопис - "Історію русів". Дослідник Юрій Барабаш зауважує, що "поєднання романтичної історичної традиції і її пафросу з елементами комедії й гротеску, релігійної суворості із франтазією, суму зі сміхом", які є рисами, які вирізняють творчість Гоголя і роблять його унікальним явищем у російській літературі, походять безпосередньо з української барокової традиції, яка на початку творчості письменника в Росії була там абсолютно невідомою, тому сприймалася як подих свіжого повітря. Бурлеск i травестія знайшла місце в російській літературі другої половини XVIII ст., як у Петрова, Котельницького, Осипова та ін. Але їхній бурлеск не осягнув такої простонародної міцної яскравості, яка виявилася у Котляревського і Гулака-Артемовського. В українському бурлеску вражає упредметнена сприймальність, повнота постатей. Гоголь засвоїв цю особливість українського бурлеску і майстерно розвинув символічну субстанціальність своїх героїв, символічних типів у творах, як Собакевича, Манілова, Хлестакова та ін. Вертепні постаті 
в їх яскравому одязі, що співають, танцюють, плачуть, сміються, зображення різних станів суспільства, святі чудеса, театральні видовища на землі і на небі - все це мусило не пройти повз Гоголя. "Техніка вертепу, яка полягає в тому, що постаті не самі рухаються, а їх рухає майстер... Гоголеві маски в постатях, змальовані яскравими штрихами... Німа фінальна сцена комедії "Ревізор", це важлива деталь, про яку Гоголь дуже дбав" [3, с. 69], чого не розуміли російські письменники. Як зауважував М. Петров, у у манускриптах Гоголя, які збереглися у Київській духовній академії, були витяги із творів українських письменників-теологів XVII-XVIII століть, отже, частково із творів епохи українського бароко. Адже він мав можливість студіювати українську світську барокову літературу (відносини із О. Бодянським, М. Максимовичем, можливість відвідувати Ватиканську бібліотеку).

Не можна не згадати про те, що Гоголь чутливо сприймав ритміку українських пісень, які приносили йому насолоду і використовував їх у своїх творах. До кінця свого життя він збирав пісні і був романтичним дослідником української пісенності.

Гоголь започаткував бароко у російській прозі. Коли Росія шукала якогось романтичного натхнення і прийшли до думки, що цього слід шукати в Україні, яка нагадувала росіянам слов'янську Італію. Вони не знали добре Україну, бо вона не була в ті часи ще так глибоко поглинута Російською імперією. Українська література розглядалася як частка системи російської імперської літератури. У Петербурзі друкувалися українські пісні, твори, наприклад, перший том "Енеїди" Івана Котляревського. От і Гоголь опинився в потрібний час і в потрібному місці.

У грудні 1833 р. Гоголь читає Пушкіну свою "Повість о том, как поссорился Иван Иванович с Иваном Никифоровичем". Того ж року написав повість "Старосветские помещики", журнал "Отечественные записки" публікує його повість "Басаврюк, или вечер накануне Ивана Купала".

У грудні 1834 р. цензура дозволила друкувати збірки "Миргород" (вийшла в 1835 р.), "Арабески" (1835р.), в яких показано духовий занепад представників поміщицько-дворянського суспільства, протиставивши їм величні і героїчні характери в повісті "Тарас Бульба". Всі ці твори були написані російською мовою, підтвердили його великий письменницький талант і принесли письменнику величезну славу.

Ліричний образ України, створений Гоголем у "Вечорах на хуторі біля Диканьки", назавжди ввійшов у європейську літературу. 
У другій частині "Вечорів..." (з 1832 р.) ліричні й героїчні замальовки України змінюються першими спробами "викривальних портретів" обивателів-"існувателів", м'який іскрометний гумор у творчості Гоголя потроху поступається місцем безжальній сатирі та сарказму. Він підписується під псевдонімом - "пасічник Рудого Панька", а для повісті "Страшний кабан" - за підписом П. Глечика, стаття "Декілька думок про викладання дітям географії" - за підписом Г. Янова, лише стаття "Жінка" підписана його прізвищем.

I раптом у Гоголя заговорило на деяку мить співчуття до свого знедоленого народу. Після своїх "Вечорів на хуторі..." він збирається писати "Історію нашої єдиної, нашої нещасної України ..., якби Ви знали, які жахливі перевороти в мені доконалися, до якої міри все в мені змордоване! Боже, скільки пережив, скільки перемучився!" (Лист від 9.11.1833 р. до М. Максимовича). Його душа плаче, ридає, напливають, як важкі петербурзькі хмари, спогади, туга за Україною, за рідними. Про це він пише згодом у своїй "Авторской исповеди": "На меня находили припадки тоски, мне самому необъяснимой, которая происходила, может быть, от моего болезненного состояния" [2, c. 14].

Багато істориків стверджують, що українські інтереси у Гоголя на цьому і вичерпались. Хоча проф. Піксанов, склавши хронологічну таблицю літературної творчості Гоголя, стверджував, що українська тематика у нього була присутня майже безперервно з 1828 до 1842 року [7, с. 63-69]. Окрім 14 творів із виразно українською тематикою, до яких належать "Вечера...", І ч. "Мёртвых душ", "Миргород", було ще 9 творів, пов'язаних з Україною.

Після праці "Миргород" у 1834-36 рр. Гоголь проникає в російську дійсність. Якщо в "Вечерах"... автор був перейнятий лише квітучою Україною, то в "Миргороді" він проникає глибше в суть життя.

Краса, сила, героїзм пов'язуються ним з козацькою Україною в творі "Тарас Бульба" (1835р.), де з великою любов'ю яскраво змальовується характер українського народу, краса української природи, звичаї. Ця повість і до сьогодні залишається неперевершеним гімном Україні, її героїчному народові, її безсмертному духові. Створюючи свою повість, Гоголь звертається до історії козацтва, пише про славних відважних отаманів, які захищали землі від поляків та мусульман. Європейські країни знали теж про героїчних i відважних українських козаків: вони були найманим військом у німецького короля Максиміліана, козаки на чолі з Юрієм Кульчицьким визволили Відень від турків і він $€$ героєм міста. Вони на чолі 3 І. Сірком визволили і відкрили шлях до моря Франції, заблокованої 
іспанцями, та можна навести й ін. приклади. Козацтво було великою організованою силою, слава якої ширилася Західною Європою.

Але сучасна Гоголю Україна стала провінцією Російської імперії, переповнена нікчемним вегетуванням, і тут у нього українські образи відійшли в тінь, ідилія поміщицьких маєтків умирає, страх огортає хвору українську душу Гоголя і викликає стогін душі. Душевне роздвоєння у Гоголя розвивалося і поглиблювалося, переростаючи в небезпечну психічну хворобу. "Журно на цьому світі, мої панове", промовляє сумно Гоголь.

У 1835 р. М. Гоголь береться за створення основної праці свого життя "Мертві душі". У листі до О. Пушкіна він пише: "Мені хочеться в цьому романі показати хоча б з одного боку всю Русь". Пише довго, болісно переробляє, і не думав, що попаде в пастку власної сміливості, за що і поплатився. В Італії пише Гоголь I т. поеми "Мертвые души", яка була надрукована в 1842 році. Ця поема була вершиною його творчості, де показано апокаліптичний образ імперії, населеної "мертвими", байдужими до своєї долі громадянами. Ця поема роздратувала особливо своєю другою частиною російських письменників не менше як "Ревізор", який був "повний злості, сміху та солі" (Гоголь). Хоча "Ревізор" розколов суспільні погляди на тих, які з ентузіазмом зустріли її, бо нічого подібного не бачила російська сцена; дійсність російського життя була передана з такою силою і правдою, що це $є$ новий період російського суспільства, виявом вільнодумства прихильників Гоголя, і на консервативно-бюрократичну частину суспільства, якому п'єса показалася демаршем. Гоголь викрив кріпосницько-поміщицьку верхівку, бюрократичний державний апарат російського царизму і висловив віру в народ.

Хоч Гоголь і не задумувався над політичною стороною, він в "Театральном разьезде после представления новой комедии" виразив свої наміри про свої особисті думки, про велике значення театру і художньої правди. Гоголь ще раніше, в 1833 р., був захоплений комедією "Володимир 3-го ступеня"; вона не була закінчена, але матеріал послужив для декількох драматичних епізодів, як "Утро делового человека", була надрукована в "Современнике", а також "Тяжба", "Лакейская", "Отрывки" та ін.

Маленьким світлом у темному тунелі був нововідкритий у Києві Університет (1834р.), ректором якого був М. Максимович, учений природознавства, етнографії, історії, фрілології, етнографії, біології. Гоголь знав ще з 1829 року і підтримував з ним дружні зв'язки. Їх поєднувало не тільки спільне зацікавлення культурною спадщиною українського народу, але й щире бажання відтворити і зберегти 
документально українську історію, традиції, звичаї. М. Максимович зацікавив і привернув Гоголя до збирання народного українського фольклору. I він, окрилений духом, знову береться до праці. Праця "Миргород" - новий етап поглиблення національної свідомості Гоголя, яка припадає на 1832-1834 роки. Цей стан помітний пізніше в творі "Арабески" (1835р.), у листуванні з Максимовичем i І. Срезневським, у поодиноких листах до Погодіна, Дмітрієва.

М. Максимович мав неабиякий вплив на М. Гоголя, що видно 3 їхнього листування. Листи Гоголя до "милого земляка" відкриті, він не мав жодних таємниць перед ним, вони вражають винятковою щирістю. Так, у листі від 2.07.1833 р., Гоголь пише М. Максимовичу: "Бросьте в самом деле кацапию, да поезжайте в гетьманщину. Я сам думаю то же сделать и на следующий год махнуть отсюда. Дурни мы, право, как рассудишь хорошенько. Для чего и чему жертвуем всем?" В іншому листі він знову пише: "Я тоже думал - туда, туда, в древний прекрасный Киев! Он наш, он не их - не правда ли? Там или вокруг него деялись дела старины нашей.... Там можно обновиться всеми силами". Минув ще рік і Гоголь запитує у Максимовича: "Что ж, едешь или нет? Влюбился же в эту старую толстую бабу Москву, от которой, кроме щей да матерщины, ничего не услышишь.... Песни нам нужно издать в Киеве. Соединившись вместе, мы такое удерем издание, какого ещё никогда ни у кого не было" [2, /10, 301, 323/]. А коли пізніше було запрошено Гоголя читати російську історію, він глибоко обурився і сказав, що йому приємніше було б ботаніку або патологію читати, аніж російську історію. Як можна ідеально вимріяну Україну поєднати з конкретною дійсністю - Росією? У своїх нарисах про повстання України він характеризує український народ як одне із визначних явищ європейської історії, як народ, який своєю спиною стримав похід монголів і татар на Європу. В нотатках про Мазепу він говорить, що російський народ схильний до деспотизму, тоді як українці - демократичні. Це видно і зараз в несправедливій війні України і Росії.

Гоголь звертається до родичів за різними відомостями про український побут, звичаї, пісні, перекази, просить розшукати "самих найстарших, закоренілих малоросіян", розшукати і переслати батькові комедії і т. ін. Він пише статтю "О малороссийских песнях" (1834 р.) із влучною характеристикою українських пісень та про зібраний фольклорний матеріал. I цей період у Гоголя був найважливішим у його житті: його українська душа дала про себе знати, запанувавши над своєю супротивницею - російською. В листі до матері у 1831 році він пише: "Какая теперь тишина в моем сердце!", а іншим 
разом пише: "... спокойствие в моей груди величайшее"... В листі до матері 22.11.1833 р., як і до Максимовича, домагається крім національного строю (одягу), також пісень: "Не можу жити без пісні. Не маєте поняття, що то за мука"... Він надавав пісням перевагу перед іншими джерелами української усної творочості, і вважав, що "Пісні для Малоросії - все: і поезія, і історія, і батьківська могила. Хто не зрозумів їх глибоко, той нічого не дізнається про колишній побут цієї квітучої частини Росії" [2, /10, 301, 323/].

Мрії про університетську катедру у Києві раз у раз не дають Гоголеві спокою.

3 кінця 1833 року готувалось відкриття Київського університету, Гоголь мріяв зайняти там кафедру історії, вивчати українську старину і хотів запросити Погодіна. В Київ запросили Максимовича на посаду ректора, і Гоголь мав надію з ним працювати. Він наполегливо опрацьовує матеріали української історії, щоб винести на суд на кафедрі Київського університету ім. Володимира Великого. Але його так і не прийняли на роботу до університету. Міністерство освіти взяло на посаду професора молодого, низькоосвіченого, який кінчив ледь курс гімназії.

Ось тут ми і втратили М. Гоголя.

Він проявив ініціативу до праці для України, поки заговорила його українська душа, треба було підтримати його. Більш активним виявилось російське суспільство, яке вчасно підхопило його і робило все, що роздвоєна душа Гоголя волала: вводять його накінець в вищі круги, знайомство Гоголя з вищим світом, з В. Жуковським, 3 С. Пушкіним, номінація на професора-ад'юнкта загальної історії Петербурзького університету - все для нього зроблено, чого він так бажав. Нарешті до нього прийшла слава, слава автора "Ревізора" (1836р.), справжня "всеросійська". Швидко спромоглися і підготовити постановку "Ревізора", прим'єра відбулася 19 квітня 1836 р. в Олександрієвському імператорському театрі в Петербурзі, на якій був присутній сам цар Микола І. Після прем'єри цар, виходячи із ложі, сказав: "Гм, що за п'єса! Всіх висміює, і більш за всіх - мене!" Комедія викривала самодержавну Росію і викликала вибух протесту. Починається нестримне цькування Гоголя. Конфрлікт Гоголя з російським суспільством ще більше загострився, бо Гоголь показав не тільки Україну, а й для контрасту - Росію. Це співставлення глибоко зачепило національні почування російських патріотів. К. Аксаков писав у листі 1842 р. до Гоголя про його "Мертві душі": "Дивіться, яке страшне, тяжке глузування в кінці цієї книжки: "Русь, куда несёшся ты, сама не знаєшь, не даёшь ответа". Інші - зі сльозами на 
очах від цілковитого відчаю: вони говорять, що той не руський, у кого серце не обливається кров'ю, при спогляданні безрадісного стану - говорять: "Гоголь не любив Росії: подивіться, яка гарна Малоросія і яка Росія" і додають: "... і зауважте, що сама природа Росії не помилувана, і погода навіть мокра і брудна" [10]. Друзі Аксакова відвернулися від Гоголя. Пушкіна уже не було в живих. Нікому було підтримати Гоголя.

Гоголь був дуже чутливий до критики і знову падає духом. Запал до українства у Гоголя вщухає. Він визнає могутню Російську імперію як історичну конечність, розвиває свій російський патріотизм і поступово гальмує свої українські почуття. І у листі від 14.08.1834 р. Гоголь пише: "Хоч як гірко душа сумує за Україною, треба, одначе, упокоритися без нарікань".

І в листі (22.03.1835 р.), написаному Максимовичу, після довгого мовчання, Гоголь уже не згадує про кафедру у Києві. Боротьба двох душ Гоголя змагалася і зробила своє: поки перша душа клопоталася навколо українських пісень, історії, палала українським патріотизмом, друга душа - потихеньку, але вперто і впевнено робила свою справу, вона затягувала Гоголя в свої тенета, сіті російськості, в коло російських письменників, і він переймається літературними російськими інтересами, хоч там він був чужим для всіх. Все це глушить український патріотизм, у нього зростає реакція російської державності проти того патріотизму, i, нарешті, перемагає друга душа: він "не знає, яка у нього душа". Все менше і менше свіжих і здорових вражень у Гоголя від першої душі, все слабше вона змагається, і стає переможеною.

Зацькований, розбитий, зламаний він шукає спасіння своєї душі, і 6.06.1836 року Гоголь покидає Росію і їде в Західну Європу, де з перервами пробув близько 13 років: побував у Німеччині у Бад Емсі (де два рази був на лікуванні), Баден-Бадені, Дюссельдорфі, Франктоурті; був Швайцарії, Франції, в Італії (8 років), в Ніцці та Римі, де і поселився там; у Чехії лікувався на курорті Марієнбад, Карлові Вари, бо мав хворий кишківник. Гоголь працює над творами: "Мертві душі", написав "Шинель", переробляє "Ревізор", "Тарас Бульба", "Портрет", "Одруження" та ін. Тут побували і російські письменники Ол. І. Тургенєв, Ів. Ол. Гончаров, автор "Обломова", тут був і М. Горький. В Італії він зближується із російськими художниками, особливо з Івановим, тут зустрічається із Смірновою та ін. Про життя Гоголя за кордоном можна ознайомитися із моєї праці [12]. Там він знаходить тимчасовий спокій; все, що пригнічувало його, залишилося там, в Петербурзі. 
У листопаді 1836 року Гоголь прибув до Парижа, де знайшов свого земляка й шкільного товариша О. Данилевського (1809-1888). Вони оселилися в невеликому помешканні по вулиці Place de la Bourse, № 12. Там він познайомився з Богданом Залєським (18021886), видатним польським поетом "української школи", який після польського повстання 1831 р. емігрував до Франції, а також 3 Адамом Міцкевичом. Гоголь не знав польської мови, але з ними він спілкувався російською мовою. В журналі "Кіевская старина" на с. 284 була надрукована в 1899 р. записка Гоголя до Богдана Залєського українською мовою (записка з 1837 року. - Д. Б.):

"Дуже-дуже було жалко, що не застав пана земляка дома. Чував, що на пана щось напало - не то сояшныца, не то завійныця (хай ій прыснытся лысый дидько), та тепер, спасибо богови, кажут начей-то пан зовсим здоров. Дай же боже, щоб на довго, на славу усій козацкій земли давав бы чернецького хлиба усякій болизни и злыдням. Та й нас бы не забував, пысульки в Рым слав. Добре б було, колы $б$ и сам туды колы-небудь прымандрував. Дуже, дуже блызькый земляк, а по серцю ще блыжчый, чим по земли. Мыкола Гоголь". [20, с. 284].

У першому своєму листі з Парижа, 12.11.1836 р. до В. Жуковського Гоголь писав: "Париж не такий поганий, як я уже собі уявляв, а що є найкраще для мене, місць для прогулянок дуже багато; одного саду Тюїлері та Елісейських полів досить на цілий день ходіння" [15, с. 415].

Незабаром, у листі до матері, Гоголь захоплено описує життя у Парижі: "Жити в ньому можна, як хочете, й дорого, й дешево, - у такій мірі дешево, як не можна навіть у Петербурзі... Вчора я був у Люврській картинній галереї, це вже вдруге, і все насилу міг вийти. Картини тут зібралися найкращі з усього світу. Був минулого тижня у відомому саду (Jardin des plantes), де зібрані всі рідкісні рослини 3 усього світу, і все на вільному повітрі. Слони, верблюди, страуси й мавпи ходять там, як у себе вдома... Увесь Париж $є$ наповнений тепер музикантами, співаками, малярами, артистами й мистцями всіх родів. Вулиці всі освітлені газом" [Там само, с. 417-418]. А в іншому листі до матері він скаржився на сльоту й вогкість: "Тут зовсім нема зими... Тутешні мешканці в літніх сюртуках ходять цілу зиму..." [Там само, с. 420].

У лютому 1837 року в Парижі, він дізнався про смерть О. Пушкіна, яка дуже його вразила.

В листі від 25.01.1837 р. до свого приятеля шкільних років М. Прокоповича Гоголь писав: "Париж - гарне місце для того, хто власне їде до Парижу, щоб пірнути в ціле його життя. Але для таких 
людей, як ми з тобою, - не думаю, хіба треба скинути з нас по 8 літ... тут усе політика, в кожному провулку і провулочку бібліотека 3 журналами. Зупинишся на вулиці чистити чоботи, тобі тичуть у руки журнал... тільки в одне життя театральне я іноді вступаю: італійська опера тут чудова! ... Я був не так давно в Théâtre Français, де святкували день народження Мольєра. Виставляли його п'єси "Тартюф" і " Удаваний хворий". Обидві були дуже добре поставлені і грані, принаймні як порівняти з тим, як їх грають у нас.... Акторів багато, дуже багато добрих... Театри всі обладнані прекрасно ..." [Там само, c. 420-423].

В листі до матері від 15.02.1837 р. Гоголь ділиться своїми враженнями про Версаль: "Палац, сади, парки, без жодного порівняння і пишніші від нашого Царського Села й побудовані з великим смаком... Я був присутній на паризькому карнавалі, де останнього дня була така сила народу, якої я ніколи ще не бачив" [Там само, с. 430].

В Парижі Гоголь писав "Мёртвые души", як свідчив його приятель П. Анненков, він не "любив тоді фрранцузької літератури, зовсім нічого не читав з французького красного письменства..." Дійсно, в творах Гоголя не має впливу французької літератури, бо він не знав фрранцузької мови і читав лише зі словником, але здібний Гоголь, як писав А. Карамзін, "досить добре розумів ії, щоб слідкувати за театрами"...

В березні 1837 року Гоголь їде до Італії, в Рим, який заполонив його душу, і він став для нього другою батьківщиною, де письменник прожив з 1837 по 1846 рр.

Париж не відігравав такої ролі в житті й творчості Гоголя, як Рим, у якому він був закоханий. Політика і громадське життя завжди для Гоголя були чужими, його захоплювала природа і мистецтво, а Рим у ті часи сприяв йому цими зацікавленнями. Гоголь вивчає пам'ятники давнини, картинні галереї, побут і фольклор італійців, він любив показувати і розказувати про Рим російським відвідувачам і приятелям. Він часто звертався до твору Карла Брюлова "Останній день Помпеї" (1833р.) і знайшов те, що наближало його до Істини: через роздуми про Бога він єднався зі світом, з Космосом та Вічністю. Він знаходив на картині мистецькі символи-застереження людству, глибину трагедії звичайної людини. Гоголь згадує й інші монументальні картини подібного змісту, як картина англійського художника Джона Мартіна "Руйнування Ніневії", "Видіння Вальтасара", "Руйнування Трої", "Загибель Геркуланума та Помпеї", якого Г. Гайне порівнював 3 видатним європейським композитором Гектором Берліозом. 
У Римі М. Гоголь любив відвідувати кав'ярню "Греко", де смакував кавою, подумки каючись у своїх гріхах, що залишив Україну, свою рідну Полтавщину. В Італії йому "легше дихалось", і небо в Італії так нагадувало йому сяюче небо України.

В листі до Бориса Левіна Гоголь писав: "Полтавщина - це ласкаве, незрівняне повітря, що його ніяк не нап'єшся, а верби над Ворсклою, де їхнє розкошисте віття срібляться мовби ще з часів Марусі Чурай, як височінь цього неба Полтавського, в його осінній, тихо сяючій блакитній небесності" [15].

В Італії, здебільшого у Римі, він живе по 1847 рік, там він знаходить тимчасовий спокій, все залишилося там, у Петербурзі. 3 Риму Гоголь пише В. Жуковському: "Я народився тут, Росія, Петербург, сніг, падлюки, департамент, професура, театр - все то мені лише снилося" [Там само].

Гоголь із захопленням пише про Італію: "... Кто был на небе, тот не захочет на землю. Словом, Европа в сравнении с Италией всё равно, что день пасмурный в сравнении с днём солнечным" [12].

В жовтні 1837 року Гоголь пише В. А. Жуковському: "Если бы вы знали, с какой радостю я бросил бы Швайцарию и полетел бы в мою душеньку, в мою красавицу Италию. Она моя! Никто в мире её не отнимет у меня! I далі: "О, Италия! Чья рука вырвет меня от сюда? Что за небо! Что за дни! Лето - не лето, весна - не весна, но лучше весны и лета, какие бывают в других углах мира. Что за воздух! Пью - не напьюсь, гляжу - не нагляжусь. В душе небо и рай. У меня теперь в Риме мало знакомых, или, лучше, почти никого. Но никогда я не был так весел, так доволен жизнью" [15].

В червні 1839 р. на запрошення Михайла Петрова (там був і російський журналіст, письменник Погодін) Гоголь приїхав на лікування кишківника, яким він хворів, до Чехії, Марієнбад (Карлові Вари), що справив на нього погане враження: "грязне, вонюче місто". Але потім він ближче ознайомився з природою Чехії, яка справила на нього велике враження. Гоголь часто організовував походи в ліс з друзями і відійшов від буденних клопотів. Він часто бував у місцевому театрі, який в майбутньому був названий його ім'ям (1952р.). Лише коли Погодін виїхав з Марієнбада, Гоголь почав думати про свої праці, особливо про роман "Мертві душі" I т., "Шинель", які готував до друку.

У вересні 1839 р. Гоголь у супроводі Погодіна приїхав до Москви і на вечорах у Аксакових читає розділи з "Мертвих душ", а у жовтні у Петербурзі - у Жуковського, у Прокоповича в присутності 
своїх давніх друзів. Похвала була загальна. У 1842 році "Мертві душі" ч. I вийшла у світ, яка сколихнула різні кола суспільства і була сприйнята вороже. Тут його недруги звинуватили Гоголя в його наклепі на дійсність (Н. А. Полевой). Але вся ця полеміка проходить за відсутності Гоголя, який у червні 1842 року виїхав знову за кордон, доручивши видання його "Творів в 4-х томах" товаришеві по Ніжинській гімназії М. Я. Прокоповичу. У 1843 році вийшов з друку 4-томник "Твори". На отримані гроші від видання Гоголь створив Фонд допомоги бідним і талановитим студентам Петербурзького і Московського університетів.

Період 1842-1846 рр. за кордоном - період важкої праці над другим томом "Мертві душі". У другій частині "Мертвих душ" Гоголь хоче показати "моральні переродження своїх героїв, намалювати майбутнє оновлене суспільство і державу". Як не дивно, що у нього були думки такі, як і у його попередника земляка-полтавця Г. Сковороди. Згадаймо, що писав Г. Сковорода про омріяну ним Горну республіку: "В горной республике всё новое: новые люди, нова тварь, новое твореніе - не так как у нас под солнцем все ветошь ветошей и суета суетствій..." [18, с. 418].

Гоголь їде до Hamburg, через Aix la Chapelle і зупинився в Baden-Baden. Часто він лікувався на відомому курорті Німеччини Baden-Baden, а також підтримував добрі відносини з засновником журналу "Europa" - August Lewald, який переклав новелу "Тарас Бульба" Гоголя і надрукував у своєму журналі. Все літо 1842 р. М. Гоголь провів у Німеччині і лише в жовтні переїхав до Риму. Він багато працює над підготовкою зібрання творів і над другим томом "Мертвих душ". "Твори. В 4-х томах" Миколи Гоголя починають виходити в 1843 році, бо на деякий час були затримані цензурою.

Початок 1845 року для Гоголя характеризується новою душевною кризою. Він починає переїжджати з курорту на курорт, щоб знайти душевну рівновагу. Вдруге Гоголь оселився в Парижі у січні 1845 р. і жив у помешканні, що підшукав йому друг граф О. П. Толстой. "Прекрасна кімната при rue de la Paix", як писала про те паризька мешканка графиня А. Вієльгорська. Проте Гоголь цього разу був не дуже задоволений французькою столицею. Потім він захворів і повернувся знову, у березні 1845 р., до Риму. В цей час до Риму приїхав Сергій Левицький на зустріч з російськими художниками, пансіонерами Імператорської академії мистецтв: Федором Іорданом (гравер), Олександром Івановим, Миколою Рамазановим, і тут він зустрічає М. Гоголя. Використавши приїзд до Риму віцепрезидента російської Академії мистецтв графа Федора Толстого, 
Левицький умовив Гоголя знятися на дагерротип разом з групою російських художників.

На початку 1845 року у Гоголя з'являються ознаки душевної кризи, хвороба почала прогресувати. Письменник їде на відпочинок, щоб "відновити свої сили" знову їде до Парижа, а у березні повертається до Франктфурта. Починаються консультації і лікування у різних медичних знаменитих медиків, переїзди з одного курорту в інший: в Галле, Берлін, Дрезден, Бад Емс і в Карлсбад.

Цікаво, що в 1845 р. Гоголь був у Карлсбаді. А. Бем, німецький дослідник, знайшов Карлсбадський альманах того часу ("Almanach de Karlsbad" за 1846 рік), де фрранцузькою мовою подано реєстр усіх відвідувачів Карлсбада в 1845 р., і там на с. 17 згадується: "Пан Микола Гоголь, українець, що живе в Москві, автор кількох російських комедій" [7, с. 74].

А у Бад Емсі, де Гоголь лікувався, в графрі Staatsangehörigkeit (громадянство), записано - українець. Так визначив свою національність М. Гоголь на курортному бланку, який він сам заповнив.

Щодо німецької літератури, то німці ставлять М. Гоголя поруч $з$ німецьким фрілософом, письменником Е.-Т.-А. Гофманом. Тому німці більш сприймали його твори франтастичної тематики. Гоголь двічі перебував в Бад Емсі на курорті, і жителі курортного міста пишалися ним, як і іншими російськими письменниками як (Ф. Достоєвським, І. Тургенєвим), про що свідчить пам'ятна дошка на будинку, де жив Гоголь.

Праця Гоголя над продовженням "Мёртвых душ" не вдавалась, він став сумніватися в своїх задумах і почав далі працювати, ставши на шлях теологічної традиції. "Про граді Божому "Блаженного Авґустина", і пише передмову до 2-го тому "Мертвих душ" (опублікована у 1846 р.) - "До читача від сочинителя" пише розв'язку "Ревізора" (опубл. 1856 р.), в якій ідея "зібраного міста" в теологічній традиції. Він впадає в суб'єктивну площину "душевного міста" окремої людини, що ставило на перший план вимоги духовного виховання і вдосконалення кожного.

Гоголь продовжує працювати над закінченням другого тому "Мертвих душ", він живе уже в Москві і лише наїздами буває в Малоросії і Петербурзі.

Окремі розділи свого твору він читає друзям і знаходить лише загальне схвалення, це стимулює його праці. Та знову переносить душевний удар. Навесні 1850 року робить спробу влаштувати свої родинні справи, пропонуючи А. М. Вієльгорській стати його дружиною, але отримує категоричну відмову. 
У жовтні Гоголь приїхав до Одеси. Стан його здоров'я покращився: він діяльний, бадьорий, веселий. Гоголь мав зустрічі з літераторами, з акторами одеської трупи. У травні 1851 року залишає Одесу, весну і літо проводить у рідних місцях, і у червні повертається до Москви, де читає ряд розділів із 2 тому "Мертвих душ"; у жовтні був присутній у Малому театрі в Москві на постановці "Ревізора", де роль Хлестакова зіграв С. В. Шумський. Він залишився задоволений виставою. 1.01.1852 р. Гоголь повідомляє Арнольда, що 2-й том "абсолютно закінчено".

Смерть Е. М. Хом'якової, сестри Н. М. Язикова, духовно близького друга Гоголя, негативно вплинула на його психіку, наступила нова криза у психіці. Його переслідує передчуття близької смерті, сумніви своїх письменницьких творів через безкінечні напади.

Другою передумовою, що допомогла остаточно зламатися українській душі Гоголя, було те, що в ті часи за кордоном про Україну як таку ніхто не знав, якщо йшла мова, то про Російську імперію. I для Гоголя поволі Україна і Росія зливаються воєдино "Русь". Реальна Батьківщина відходить від Гоголя, місце ії̈ заповнює вигадана ще в Петербурзі і признана за кордоном абстракція "РусіРосії". I Гоголь на це спокійно пристає: "Оточує мене тут чужа стихія, - пише Гоголь до Погодіна з Женеви 22.10.1836 р., - але в серці моїм Русь не та недобра, але єдино гарна Русь ..." від літературного українського життя він все далі і далі відходить, перестає розуміти його, все рідне робиться йому чужим. Звичайно, ворогом українству Гоголь не був, бо на це б не дозволила його українська душа, з якою він народився, яка в кожній людині знаходиться в підсвідомості до кінця її життя.

І де б Гоголь не був, у нього виникають асоціації, пов'язані з Україною: перебуваючи в Іспанії, на майдані, який йому "яскравістю нагадує "сорочинські ярмарки" (Лист до мами від 12.10.1849).

У травні 1847 дорогою від Неаполя до Парижа, а потім до Німеччини, Гоголь отримав повідомлення про велику критичну бурю від його опублікованої у Петербурзі "Вибрані місця з листування 3 друзями", передмовою до яких став "Заповіт", написаний у Гамбурзі 1845 року. Книга викликала гнівну бурю славнозвісного ворога українства В. Бєлінського в "Листі до Гоголя" за реакційну її спрямованість. Ця дуель Гоголь-Бєлінський привела до того, що їх шляхи розійшлися назавжди. Гоголь важко пережив провал своєї книги. Лише П. А. Плетньов і О. О. Смирнова змогли підтримати його в цю важку хвилину. Ця полеміка була для Гоголя чужою; за прикладом Пушкіна, він вважав себе народженим "для звуков сладких и молитв". 
В "Авторській сповіді" М. Гоголь писав: "Душа моя знемогла, я думав, що у книзі моїй - швидше зерно примирення, а не розбрату... Мені тільки здалося безсумнівною істиною, що я зовсім не знаю Росії, що чимало змінилося відтоді, як я в ній не був... . Дивуюсь сам, як я ще залишився живим".

Причиною остаточного занепаду української національної душі $\epsilon$ і сам Гоголь, який вибрав для себе дві душі, переполовинивши свою душу, що є причиною його душевних мук, які підірвали його психіку, творчий талант і призвели до передчасної смерті. Бо як народ єдиний, він стає нацією і має силу, так і людина цієї нації повинна мати єдину душу. I якби Гоголь міг вибрати єдиний шлях, єдину Батьківщину, то він мав би і єдину здорову душу, як Т. Шевченко, Леся Українка, П. Куліш і ін., які хоч і писали російською мовою, але до кінця служили своєму народові. "У Гоголя була присутня українськість, українська пісня звучала в його душі, навіть національний український танець гопак не забув, який відтанцював ще за півроку до своєї смерті в маєтку С. Аксакова-Абрамцева під Москвою, де гостював пізнім літом 1851року" [6, с. 74].

Уже після Нового 1852 року книга "Мертві душі" 2-й том була закінчена. Але у кінці січня стають явні ознаки депресії. I нікому в голову не прийшло забрати цю книгу, щоб нічого не трапилося. В останні роки Гоголь жив у Москві на Нікітському бульварі, будинок № 7.

3 кінця 1852 року Гоголь жив у домі графа А. П. Толстого, там гостював протоєрей Матфей (Константиновський), з яким Гоголь був знайомий чотири роки. Гоголь запропонував йому прочитати частини із другого тому "Мёртвых душ"; той повернув йому 3 недоброю оцінкою і запропонував знищити манускрипт. Гоголь був розчарований і перестає вживати їжу, 10 лютого він попросив графа Толстого передати портфель з рукописами митрополиту Філарету, але граф відмовив йому, щоб підтримати його морально.

7 лютого 1852 р. він сповідається і причащається. О 3-й годині ночі 11 лютого, за десять днів до смерті, Гоголь розбудив слугу Семена і наказав розтопити піч і принести йому портфель із шафи. Він вийняв всі зошити з рукописами, кинув їх у камін. Він пише заповіт, спалює рукопис другого тому "Мёртвых душ", приносячи її в жертву Богові, про що згодом жалкує у своїх листах до друзів. Гоголь пояснював, що причиною $є$ те, що в книзі недостатньо були вказані "шляхи і дороги" до ідеалу". Збереглися лише листи Пушкіна, Жуковського та його особисті речі та неповних 5 розділів "Мертвих душ" 2-го тому. 
Здоров'я письменника погіршується, він впадає в депресію, відмовився від їжі, від лікування, не приймає відвідувачів і готується до смерті. За кілька днів Гоголь доводить свій організм до остаточного виснаження. 21.02.1852 р., в четвер, в будинку Тализіна він помер. Гоголя поховали 24.02.1852 р. на цвинтарі Свято-Данилівського монастиря в Москві. В 1930 р. монастир був закритий, цвинтар ліквідовано. 31.05.1931 р. прах Гоголя був перенесений на Новодівицьке кладовище. Туди була перенесена Голгофа (чорний надмогильний камінь). А в 1952 р. на могилі Гоголя було встановлено новий пам'ятник: И. А. Аксаков вибрав "чорноморський граніт, з якої був виготовлений постамент з бюстом Гоголя, робота скульптора Томського, на якому написано: "Великому русскому художнику от советского правительства".

Чорну плиту (Голгофу), яка була уже почищена від надпису в майстерні власниками, викупила вдова М. А. Булгакова, Олена Сергіївна Булгакова, вона була підготовлена й установлена над могилою Михайла Афанасійовича. Так здійснилася мрія М. А. Булгакова: "Учитель, укрой меня своей чугунной шинелью" [16]. ${ }^{1}$

\section{Література}

1. Єфремов С. Між двома душами. Микола Гоголь. Київ: Вік, 1909.

2. Гоголь Н. В. Полное собрание сочинений: в 14 т. Москва, 1937-1988.

3. Бойко-Блохин Ю. До основ світовідчування М. В. Гоголя. Науковий збірник УВАН / ред. М. Антонович. Нью-Йорк, 1999 (1945-1950-1995). T. IV. C. $59-75$.

4. Деко О. Солов"ї співають на світанні. Київ, 1988.

5. Пискунов Н. Украинские повести Гоголя. О классиках: сборник. Москва, 1933.

6. Маланюк Є. Ґоголь - Ґоґоль. Розбудова Держави. Київ, 2002. Ч. 1-4.

7. Барабаш Ю. Я. Гоголь: барокко. Современная драматургия. 1992. № 2. 1956.

8. Онацький Євген. Завзяття чи спокуса самовиправдання. Париж,

9. Барабаш Ю. Г. С. Сковорода і М. В. Гоголь (до питань про гоголівське бароко). Сковорода Григорій. Образ мислителя. Київ, 1997.

10. Тетеріна Дарина. Душевна драма М. Гоголя. Вибрані твори: в семи томах. Мюнхен-Київ, 2004. Т. 7. С. 81-103.

11. Гусев В. Туда! Туда! В Киев... День. - 1999, 2 квітня.

12. Блохин Д. Гоголь в Європі. Література і культура Полісся. Ніжин, 2013.

13. Agustino Boniato-Denkmal von N. Gogol in Rom // Italicaю №1 (34). Ferbruar-März. 2003. URL: http//www.ice-nut.ru .

\footnotetext{
${ }^{1}$ При написанні цієї статті використані матеріали із Енциклопедичного словника, за що вдячні.
} 
14. Тетеріна Дарина. Душевна драма Гоголя. Вибрані твори: в шести томах. Мюнхен-Київ, 2004. Т. 6. С. 81-103.

15. Письма Н. В. Гоголя / редакция В. И. Шенрока. Т. І. СПб 1901.

16. Лакшина В. Я. Воспоминания о Михаиле Булгакове. Москва: Советский писатель, 1988. С. 420.

17. Абліцов Віталій. Сумно на цьому світі, пранове Літературний ярмарок. URL:http://www.lit-jarmarok.in.ua/index.php?obtion_com_content@task-view @id-772@It...

18. Сковорода Григорій. Твори: в двох томах. Київ. 1961. Т. 1.

19. Вікіпедія: URL:http://uk.wikipedia. org

20. Кіевская Старина 1899, Харків. С. 284

\section{References}

1. Yefremov S. Mizh dvoma dushami. Mikola Gogol. Kiyiv: Vik, 1909.

2. Gogol N. V. Polnoe sobranie sochinenij v 14 tt. Moskva, 1937-1988.

3. Bojko-Blohin Yu. Do osnov svitovidchuvannya M. V. Gogolya. Naukovij zbirnik UVAN Red. M. Antonovich. Nyu-Jork, 1999 (1945-1950-1995). T. IV. C. 59-75.

4. Deko O. Solov'yi spivayut na svitanni. Kiyiv, 1988.

5. Piskunov N. Ukrainskie povesti Gogolya. O klassikah: sbornik. Moskva, 1933.

6. Malanyuk Ye. Gogol - Gogol. Rozbudova Derzhavi. Kiyiv, 2002. Ch. 1-4.

7. Barabash Yu. Ya. Gogol: barokko. Sovremennaya dramaturgiya. 1992. № 2 . 1956.

8. Onackij Yevgen. Zavzyattya chi spokusa samovipravdannya. Parizh,

9. Barabash Yu. G. S. Skovoroda i M. V. Gogol (do pitan pro gogoliv-ske baroko). Skovoroda Grigorij. Obraz mislitelya. Kiyiv, 1997.

10. Teterina Darina. Dushevna drama M. Gogolya. Vibrani tvori: v semi tomah. Myunhen-Kiyiv, 2004. T. 7. S. 81-103.

11. Gusev V. Tuda! Tuda! V Kiev... Den. - 1999, 2 kvitnya.

12. Blohin D. Gogol v Yevropi. Literatura i kultura Polissya. Nizhin, 2013.

13. Agustino Boniato-Denkmal von N. Gogol in Rom // Italicayu №1 (34). Ferbruar-Marz. 2003. URL: http//www.ice-nut.ru .

14. Teterina Darina. Dushevna drama Gogolya. Vibrani tvori: v shesti tomah. Myunhen-Kiyiv, 2004. T. 6. S. 81-103.

15. Pisma N. V. Gogolya. Redakciya V. I. Shenroka. - T. I. SPb 1901.

16. Lakshina V. Ya. Vospominaniya o Mihaile Bulgakove. Moskva: Sovetskij pisatel, 1988. S. 420.

17. Ablicov Vitalij. Sumno na comu sviti, pranove Literaturnij yarmarok. URL: http://www.lit-jarmarok.in.ua/index.php?obtion_com_content@task-view@id-772@lt...

18. Skovoroda Grigorij. Tvori: v dvoh tomah. Kiyiv. 1961. T. 1.

19. Vikipediya: URL:http://uk.wikipedia. org

20. Kievskaya Starina. 1899, Harkiv. S. 284 


\section{Дариана Блохин}

доктор философии в области педагогики, професор, член-корр. Академии наук у НьюЙорке, почетный академик Академии наук Высшей школы Украины

\section{Причини украинского национального самоубийства Николая Гоголя}

В статье автор освещает причины украинского национального самоубийства Николая Гоголя, связи его с Западной Европой, где он знакомится с культурой и жизнью других народов. Его пребывание за границей обусловлено преследованием со стороны русского царского правительства как украинца, который писал свои труды на русском языке украинской тематики и имел проблемы в типографиях. Позже он избрал тематику из русской жизни при царизме, которая была пронизана правдой, ибо он осуждал тогдашний строй, что вызвало также недовольство царской власти. Часто он лечился за границей в Германии, Чехии и других государствах.

Ключевые слова: Баден-Баден, Рим, Париж, Любек; Залесский, Тургенев, Погодин; театр, Полтава, украинские обычаи, козацкий род, украинские песни.

\section{Dariana Blokhyn}

doctor of philosophy in the field of pedagogy, professor, member-corr. Academy of Sciences in New York, Honorary Academician of the Academy of Sciences of the Higher School of Ukraine

\section{The reasons for Mykola Gogol' national suicida}

In this article the Author describes his own experiences about life and culture in Western Europe which he gathered by traveller throughout the European continent.

The Author was very disappointed with the way the Russian Government has prosecuted him because of his Ukrainian heritage. Since he wrote about the Ukrainian situation he had difficulties finding Ukrainian publishers who were willing to publish his articles and books.

In his later years he wrote about his disappointment with the Russian Imperialism and openly criticised the Russian government.

Key words: Italy, Rome, Bad Ems, Documents, theatre, Ukrainian culture and costumes, Ukrainian kosakes. 